Article

\title{
Exploring the Synergistic Anticancer Potential of Benzofuran-Oxadiazoles and Triazoles: Improved Ultrasound- and Microwave-Assisted Synthesis, Molecular Docking, Hemolytic, Thrombolytic and Anticancer Evaluation of Furan-Based Molecules
}

\author{
Ali Irfan ${ }^{1}\left(\mathbb{D}\right.$, Sadia Faiz ${ }^{1}$, Azhar Rasul ${ }^{2} \mathbb{D}$, Rehman Zafar $^{3}\left(\mathbb{D}\right.$, Ameer Fawad Zahoor $^{1, *(\mathbb{D})}$ \\ Katarzyna Kotwica-Mojzych ${ }^{4}$ and Mariusz Mojzych ${ }^{5, *(D)}$
}

check for

updates

Citation: Irfan, A.; Faiz, S.; Rasul, A.; Zafar, R.; Zahoor, A.F.;

Kotwica-Mojzych, K.; Mojzych, M. Exploring the Synergistic Anticancer Potential of Benzofuran-Oxadiazoles and Triazoles: Improved Ultrasoundand Microwave-Assisted Synthesis, Molecular Docking, Hemolytic, Thrombolytic and Anticancer Evaluation of Furan-Based Molecules. Molecules 2022, 27, 1023.

https://doi.org/10.3390/

molecules 27031023

Academic Editor:

Artur M. S. Silva

Received: 26 December 2021

Accepted: 27 January 2022

Published: 2 February 2022

Publisher's Note: MDPI stays neutral with regard to jurisdictional claims in published maps and institutional affiliations.

Copyright: () 2022 by the authors Licensee MDPI, Basel, Switzerland. This article is an open access article distributed under the terms and conditions of the Creative Commons Attribution (CC BY) license (https:// creativecommons.org/licenses/by/ $4.0 /)$.
1 Department of Chemistry, Government College University Faisalabad, Faisalabad 38000, Pakistan; raialiirfan@gmail.com (A.I.); sadia.faiz01@gmail.com (S.F.)

2 Department of Zoology, Government College University Faisalabad, Faisalabad 38000, Pakistan; drazharrasul@gmail.com

3 Department of Pharmaceutical Chemistry, Riphah International University, Islamabad 44000, Pakistan; rehmanzafar016@gmail.com

4 Department of Histology, Embryology and Cytophysiology, Medical University of Lublin, Radziwiłłowska 11 20-080 Lublin, Poland; katarzynakotwicamojzych@umlub.pl

5 Department of Chemistry, Siedlce University of Natural Sciences and Humanities, 3-Go Maja 54, 08-110 Siedlce, Poland

* Correspondence: fawad.zahoor@gcuf.edu.pk or fawad.zahoor@gmail.com (A.F.Z.); mariusz.mojzych@uph.edu.pl or mmojzych@yahoo.com (M.M.)

Abstract: Ultrasound- and microwave-assisted green synthetic strategies were applied to furnish benzofuran-oxadiazole $\mathbf{5 a - g}$ and benzofuran-triazole $\mathbf{7 a - h}$ derivatives in good to excellent yields (60-96\%), in comparison with conventional methods (36-80\% yield). These synthesized derivatives were screened for hemolysis, thrombolysis and anticancer therapeutic potential against an A549 lung cancer cell line using an MTT assay. Derivatives $7 \mathbf{b}(0.1 \%)$ and $5 \mathbf{e}(0.5 \%)$ showed the least toxicity against RBCs. Hybrid 7f showed excellent thrombolysis activity $(61.4 \%)$ when compared against reference ABTS. The highest anticancer activity was displayed by the $\mathbf{5 d}$ structural hybridwith cell viability $27.49 \pm 1.90$ and $\mathrm{IC}_{50} 6.3 \pm 0.7 \mu \mathrm{M}$ values, which were considerably lower than the reference drug crizotinib $\left(\mathrm{IC}_{50} 8.54 \pm 0.84 \mu \mathrm{M}\right)$. Conformational analysis revealed the spatial arrangement of compound 5d, which demonstrated its significant potency in comparison with crizotinib; therefore, scaffold $5 \mathbf{d}$ would be a promising anticancer agent on the basis of cytotoxicity studies, as well as in silico modeling studies.

Keywords: benzofuran-oxadiazole; benzofuran-triazole; computational modeling; hemolytic activities; thrombolytic activities; anticancer activities

\section{Introduction}

In recent years, natural- and synthetic furan-based (Figure 1) based chemotherapeutic agents have attracted the attention of medicinal chemists to develop novel pharmacological agents with diverse pharmacophores andhave expanded the scope and treatment of various diseases [1-3]. 


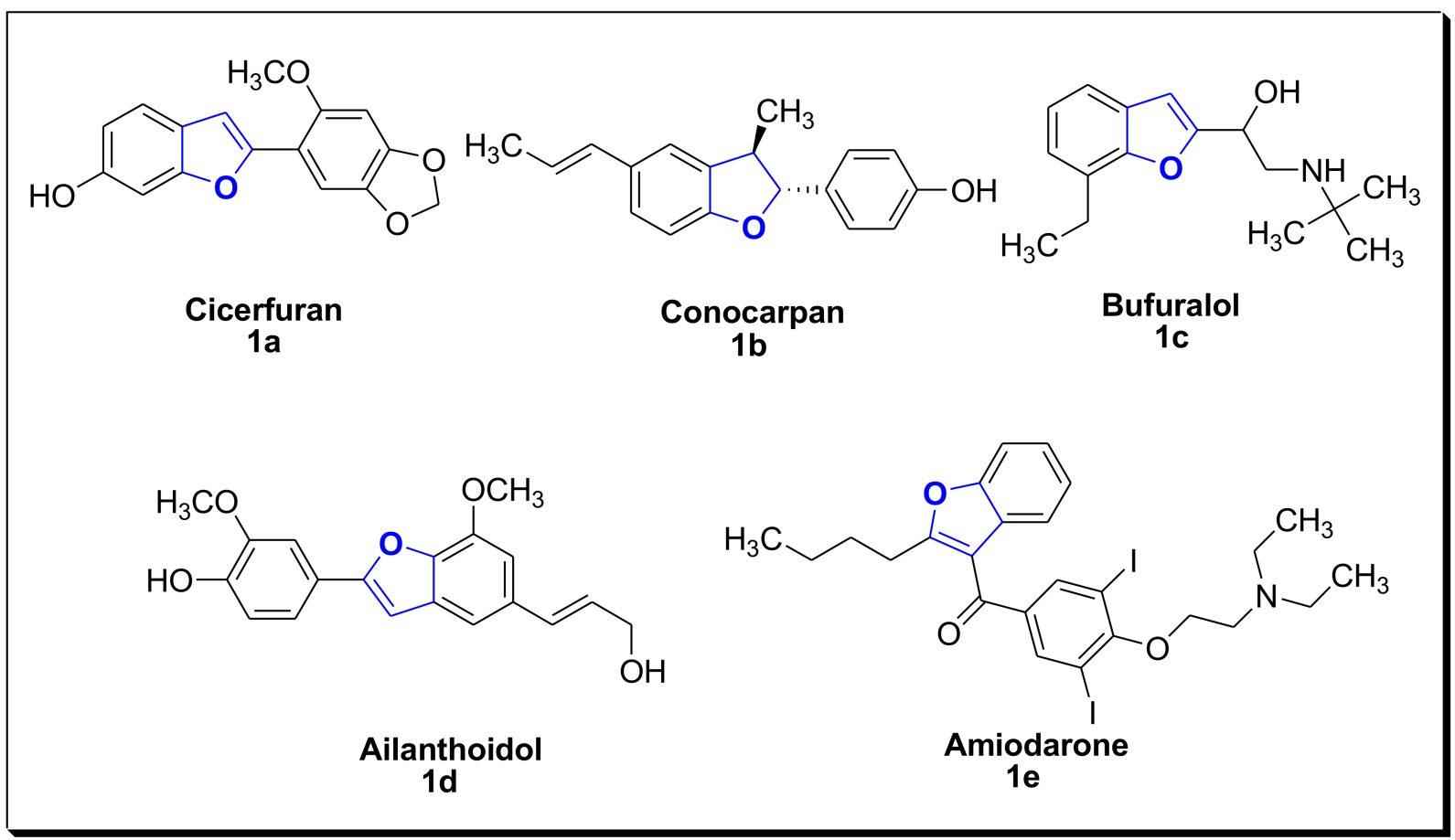

Figure 1. Structures of natural and synthetic furan derivatives.

Heterocyclic benzofurans are the basic structural units of biologically active families of natural products such as egonol, homoegonol and moracin [4]. Natural and synthetic furan derivatives exhibit profound physiological and chemotherapeutic potential against a wide variety of pathogens by displaying antimicrobial, antioxidant [5], antitubulin [6], anti-inflammatory [7], antiviral [8], antihyperglycemic [9], analgesic [10,11], anticancer [11,12], antifungal [13] and antipyretic activities [14]. The therapeutic profile of furan-based molecules has attracted medicinal researchers to design and develop anticancer agents which could play a pivotal role in cancer therapy $[1,15,16]$. In addition to this, oxadiazole and triazole ring systems, which are part of many natural products, have become the focus of pharmacologists and medicinal chemists on account of their medicinal and pharmacology activities, especially in the field of oncology $[17,18]$.

Cancer is a notably complex, prominent and lethal disease which poses a serious human health problem; ithasresulted in 7.6 million deaths globally, and this number is expected to reach 13 million by 2030 [19-21]. Naturally occurring benzofuran derivatives such as denthyrsin and HIBE (1-(6-hydroxy-2-isopropenyl-1-benzofuran-5-yl)-1-ethanone) displayed cytotoxic potential against ovarian cancer and human breast cancer cell lines [22,23]. Sulfonamide scaffolds of benzofuran-imidazopyridines showed anticancer activity against ovarian cancer, MCF-7, lung cancer and colon cancer [24]. Benzofuran-oxadiazole hybrids exhibited significant cytotoxicity against pancreatic cancer and colon cancer cell lines in vitro [25]. The 2-aryl benzo furan-appended 4-aminoquinazoline structural motifs significantly inhibited the epidermal growth factor receptortyrosine kinase phosphorylation in vitro against human lung cancer, cervical cancer, colorectal adenocarcinoma and hepatocellular carcinoma cell lines [26]. The benzofuran-carboxylic acid hybrids proved to be the best antiproliferative agents against breast cancer cell lines and significant inhibitors of carbonic anhydrases [27]. Thiazolodin-4-one benzofuran derivatives exhibited remarkable antitumor activity against human HEPG2 cell lines [28]. Different furan-based anticancer agents are listed in Figure 2 [1]. 


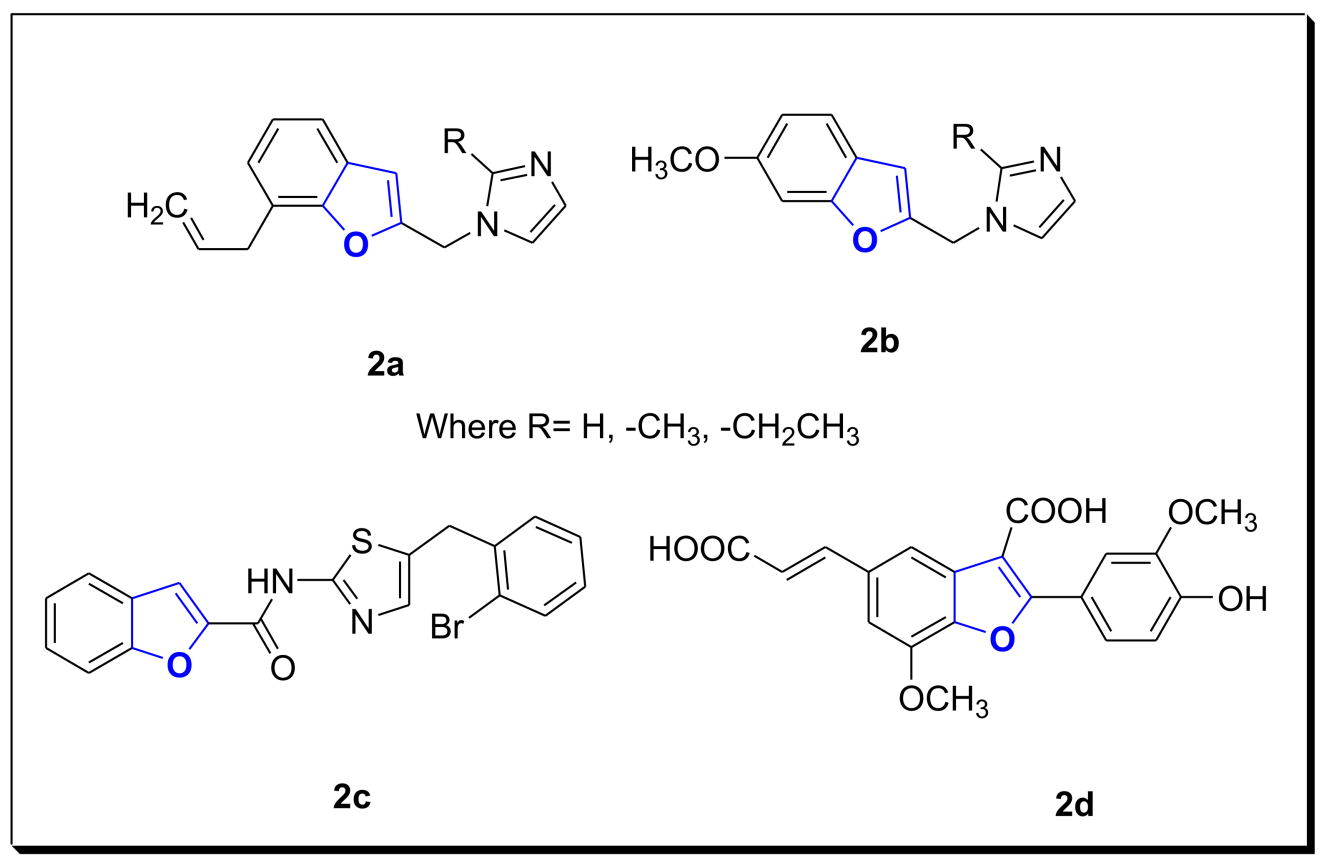

Figure 2. Structures of some synthetic anticancer benzofuran derivatives.

Continuing our previous research work towards the synthesis of benzofuran-based oxadiazole and triazole hybrids using a conventional approach [29], here, our group applied green synthetic strategies such as ultrasonic- and microwave-assisted synthetic approaches to achieve environmentally friendly synthesis with maximum production of benzofuranoxadiazole and triazolestructural hybrids over shorter reaction times. The synthesized molecules were further evaluated for their hemolytic, thrombolytic and anticancer potential.

\section{Materials and Methods}

\subsection{Chemistry}

Ultrasonic irradiation and microwave-assisted experiments were performed, respectively, in an ultrasonic cleaner bath (Model 1510, $115 \mathrm{v}, 1.9 \mathrm{~L}$ ) with a mechanical timer and heater switch and at a frequency of $47 \mathrm{kHz}$, and with microwave apparatus (Model EA$180 \mathrm{M}$ ) witha frequency of $2450 \mathrm{~Hz}$ and power consumption of 1150 watt. Analytical-grade solvents and reagents were used; these were purchased from Merck, Alfa Aesar and SigmaAldrich through local suppliers. The reaction progress was monitored using pre-coated silica gel plates. The synthesized scaffolds were purified using the column chromatographic technique and by the process of recrystallization in ethanol and methanol solvents.

\subsection{General Ultrasound-and Microwave-Assisted Synthetic Protocols for Benzofuran-Oxadiazole Hybrids (5a-g) and Benzofuran-Triazole Derivatives (7a-h)}

Method A: Ultrasound-assisted method [30]. The substituted S-alkylated oxadiazoleand triazole-based benzofuran derivatives were afforded by dissolving 5-(benzofuran-2yl)-1,3,4-oxadiazole-2-thiol 3 (0.03 g, $0.137 \mathrm{mmol})$ and 5-(benzofuran-2-yl)-4-phenyl-4H1,2,4-triazole-3-thiol 6 ( $0.03 \mathrm{~g}, 0.103 \mathrm{mmol})$ inacetonitrile $(15 \mathrm{~mL})$. Pyridine $(0.213 \mathrm{mmol})$ was added, and the reaction mixture was stirred for $15 \mathrm{~min}$ at $0{ }^{\circ} \mathrm{C}$. The substituted bromoacetanilides $4 \mathbf{a}-\mathbf{g}(0.24 \mathrm{mmol})$ were added, and the reaction mixture was sonicated at $40{ }^{\circ} \mathrm{C}$ for $30 \mathrm{~min}$, as shown in Scheme 1 . The reaction was monitored viathin-layer chromatography. On completion of the reaction, petroleum ether was added to the mixture with continuous stirring to obtain the final products in the form of precipitates, which were filtered, washed with distilled water and purified. 


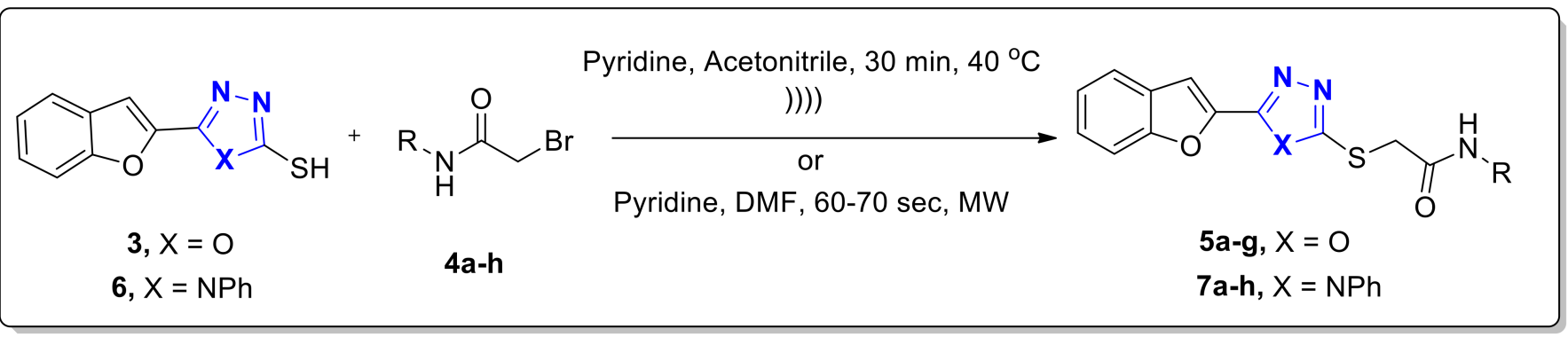

Scheme 1. Synthetic pathway for microwave/ultrasound-assisted synthesis of S-alkylated oxadiazole/triazole-based benzofuran derivatives.

Method B: Microwave-assisted method [31-33]. Benzofuran-oxadiazole hybrid 3 (0.03 g, $0.137 \mathrm{mmol}$ ) and 5-(benzofuran-2-yl)-4-phenyl-4H-1,2,4-triazole-3-thiol 6 (0.03 g, $0.103 \mathrm{mmol})$ were dissolved in DMF $(25 \mathrm{~mL})$. Pyridine $(0.213 \mathrm{mmol})$ was added to the reaction mixtureand stirred for $15 \mathrm{~min}$ at $0{ }^{\circ} \mathrm{C}$. The substituted bromoacetanilide derivatives $4 \mathbf{a}-\mathbf{g}(0.24 \mathrm{mmol})$ werethen added, and the reaction mixture was irradiated in a microwave oven for 60-70s, respectively, as depicted in Scheme 1. After completion of the reaction, petroleum ether was added to the reaction mixture with continuous stirring to obtain the final products in the form of precipitates. The precipitates were filtered, washed with distilled waterand purified by recrystallization. The advantages of these preparatory protocols are simplicity, very short reaction times, generality and the elaboration of substituted benzofuran-oxadiazole and benzofuran-triazole with high to excellent yields compared toconventional synthetic approaches and microwave methods already cited for generally synthetic approaches for oxadiazole and triazole derivatives, and specifically benzofuran-oxadiazole and benzofuran-triazole scaffolds [29,34-39].

\subsection{Biological Evaluation}

Oxadiazole- and triazole-based benzofuran derivatives were evaluated for hemolysis, thrombolysis and anticancer activity.

\subsubsection{Hemolysis Assay}

A fresh blood sample $(5 \mathrm{~mL})$ from a healthy donor was collected in an EDTA tube. The blood was transferred to microcentrifuge tubes and centrifugedfor $5 \mathrm{~min}$ at $1000 \mathrm{rpm}$ to obtain the red blood cells (RBCs). The supernatant was then discarded, and the RBCpellet was washed three times with phosphate-buffered saline (PBS). The RBC pellet was collected after washing and $20 \mu \mathrm{L}$ of sample solution in DMSO was added. The tubes were incubated at $37^{\circ} \mathrm{C}$ for $60 \mathrm{~min}$. Having been removed from the incubator, the tubes were recentrifuged at 13,000 rpm for $5 \mathrm{~min}$. The supernatant was collected and diluted with chilled PBS solution. Absorbance was recordedat $517 \mathrm{~nm}$. ABTS was used as a positive control, while DMSO was employed as a negative control in this protocol. The experiment wasconducted in triplicate, and the RBC lysis percentage was calculated using this formula [40]:

$$
\% \text { Age hemolysis }=\frac{\text { Absorbance of sample }- \text { Absorbance of negative control } \times 100}{\text { Absorbance of positive control }}
$$

\subsubsection{Thrombolysis Assay}

The thrombolytic assay was performedaccording tomethodologyin the literature [41]. A blood sample $(3 \mathrm{~mL})$ was collected from a healthy human donor, and $500 \mu \mathrm{L}$ was transferred to pre-weighed, clean Eppendorf tubes. The tubes containing the blood wereweighed again andincubatedfor $1 \mathrm{~h}$ at $37^{\circ} \mathrm{C}$ to induce clot formation. The serum was then discarded, and the tube containing theclot was weighed. An amount of $40 \mu \mathrm{L}$ of sample solution in DMSO was added to the clot.The tubes were again incubated for $3 \mathrm{~h}$ at $37^{\circ} \mathrm{C}$, and the lysis resultswere observed. ABTS was used as a positivecontrol, while DMSO was used as a 
negative control in this assay. The experiment was performed in triplicate, and the lysis percentage was calculated using the formula below:

$$
\% \text { Age clot lysis }=\frac{\text { Initial clot weight }- \text { Final clot weight } \times 100}{\text { Initial clot weight }}
$$

\subsubsection{MTT Assay}

Preparation of Cell Culture

The human lung cancer cell line A549 was cultured in Dulbecco's modified Eagle medium (DMEM), composed of 10\% FBS (fetal bovine serum), 100 units $/ \mathrm{mL}$ of penicillin $(1 \%)$ and $100 \mu \mathrm{g} / \mathrm{mL}$ of streptomycin (1\%), with $5 \% \mathrm{CO}_{2}$ (carbon dioxide) at $37^{\circ} \mathrm{C}$ in a moistened atmosphere. The A549 cell line was treated with synthesized compounds in a final concentration of DMSO (dimethyl sulfoxide) of less than $1 \%$.

\section{Determination of Cell Viability}

The cytotoxic therapeutic potential of synthesized structural hybrids was evaluated usinga standard MTT (3-(4,5-dimethylthiazol-2-yl)-2,5-diphenyltetrazolium bromide) assay. The cells of theA549 cell line were grown, overnight, in a microculture of 96-well plates. The A549 cells were supplemented with different concentrations of compounds for $48 \mathrm{~h}$ and further incubated with $20 \mu \mathrm{L}$ of MTT mixture $(5 \mathrm{mg} / \mathrm{mL})$ for $4 \mathrm{~h}$ at $37^{\circ} \mathrm{C}$. Following this, $150 \mu \mathrm{L}$ of control DMSO was added to formazan crystals.The percentage of cell viability was determined viaquantified absorbance in a microplate readerat $490 \mathrm{~nm}$ wavelength [42]

\subsubsection{Molecular Docking Studies}

The compound $\mathbf{5 d}$ with a higher pharmacological therapeutic potential was subjected to in silico studies to delineate the mechanism of anticancer activity against lung cancer A549cell lines. The molecular docking studies of these synthesized compounds at a targeted protein were carried out using auto dock Vina 1.1.2 software intermitted with PyRx. The runs of docking were achieved with grid box coordinates of $-7.65,-28.27$ and 43.34 for $\mathrm{x}, \mathrm{y}$ and $\mathrm{z}$, respectively. Considering the important role of signaling parameters in cancer, receptors of ALK (anaplastic lymphoma kinase) present an established target to evaluate the anticancer therapeutic potential of synthesized compounds $[43,44]$. To accomplish computational studies against this target, the crystallographic structure of anaplastic lymphoma kinase in conjunctionwith crizotinib having PDB ID: 2XP2 was obtained from the RCSB protein data bank; it was saved in Pdb formatafter the removal of water molecules and the co-crystallization ofthe ligand with the addition of polar hydrogen. The structure of the co-crystallized ligand crizotinib has been nominated as a potential therapeutic moiety against ALK targets; the structure of the synthesized compound $\mathbf{5 d}$ was selected because of its marked experimental results. The structures were drawn on Chemdraw 20 professional software (chemoffice) and saved as a mol file [45,46]. Following this, energy minimization and polar hydrogen addition were performed, and structures were saved in Pdb format through Bio via Discovery Studio Visualizer (DSV), as shown in Figure 3. The results in the form of pictures were processed through the latest versions of Pymol and Ligplot plus software. 


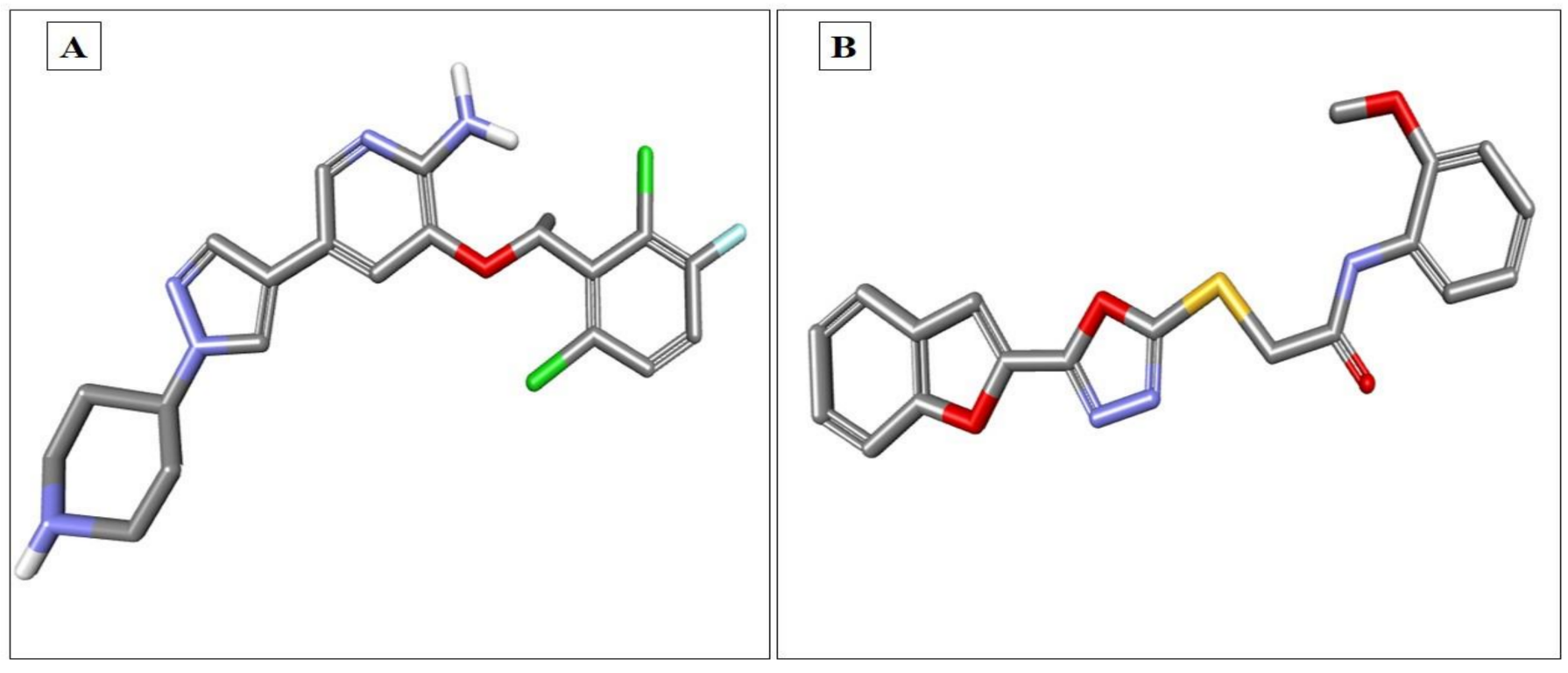

Figure 3. (A) 3D model of crizotinib with carbons (gray), oxygen (red), nitrogen (blue), fluorine (sky blue) and chlorine (green) shown; (B) 3D model of compound 5d with carbons (gray), oxygen (red), sulfur (yellow), nitrogen (blue) shown.

\subsection{Statistical Data}

The statistical data analysis was performed by using prism. All the measurements were carried out in triplicate, and the results are depicted as mean $\pm S D$.

\section{Results and Discussions}

\subsection{Chemistry}

3.1.1. Ultrasound- and Microwave-Assisted Synthesis of Oxadiazole-Based Benzofuran Derivatives $(5 \mathbf{a}-\mathbf{g})$

Ultrasound- and microwave-assisted green reactions are environmentally friendly, time saving, economical and good yield methodologies, and were adopted as depicted in Scheme 1. The conventional approach of synthesizing benzofuran-oxadiazole was already reported [29] as affording compounds in moderate to good (36-80\%) yields but required a longer period of time to complete the reaction. This study was initiated to increase the yield and reduce the time of synthesized derivatives by applying ultrasoundand microwave-assisted approaches to achieve benzofuran-oxadiazole derivatives. In the ultrasound- and microwave-assisted approaches, the scaffold 5-(benzofuran-2-yl)-1,3,4oxadiazole-2-thiol $\mathbf{3}$ was coupled with substituted bromoacetanilide derivatives $\mathbf{4 a - h}$ to synthesize corresponding $S$-alkylated products of benzofuran-oxadiazole $5 \mathbf{a}-\mathbf{g}$ in good to excellent yields, as depicted in Table 1 . The ultrasound-assisted strategy yielded products of $60-86 \%$ in $30 \mathrm{~min}$ at $40{ }^{\circ} \mathrm{C}$, compared withthe conventional method, which afforded products of $36-80 \%$ in $24 \mathrm{~h}$. The microwave approach was much more efficient in that the maximum yield of products (69-94\%) was obtained in the very short duration of $60 \mathrm{~s}$. The benzofuran-oxadiazole derivative $\mathbf{5} \mathbf{d}$ was achieved withthe maximum yield, while the derivative $5 \mathbf{f}$ was obtained withthe least yield via ultrasonication and microwave irradiation approaches, as mentioned in Table 1. 
Table 1. Yields of benzofuran-oxadiazole derivatives via conventional, ultrasound- and microwaveassisted synthetic approaches.

\begin{tabular}{|c|c|c|c|c|c|c|}
\hline \multirow[b]{2}{*}{ Compounds } & \multirow[b]{2}{*}{ R-NH } & \multicolumn{3}{|c|}{ Products Percentage Yields } & \multicolumn{2}{|c|}{ m.p. $\left({ }^{\circ} \mathrm{C}\right)$} \\
\hline & & $\begin{array}{c}\text { Conventional } \\
\text { Approach } \\
\text { (Faiz S. et al.) } \\
\text { [29] }\end{array}$ & $\begin{array}{l}\text { Ultrasound- } \\
\text { Assisted } \\
\text { Approach } \\
\text { (This Work) }\end{array}$ & $\begin{array}{l}\text { Microwave- } \\
\text { Assisted } \\
\text { Approach } \\
\text { (This Work) }\end{array}$ & Found & $\begin{array}{c}\text { Reported } \\
\text { (Faiz S. et al.) } \\
\text { [29] }\end{array}$ \\
\hline $5 \mathbf{a}$ & & 63 & 70 & 75 & 212 & $212-214$ \\
\hline $5 b$ & & 53 & 66 & 70 & $181-182$ & 180-182 \\
\hline $5 c$ & & 59 & 68 & 75 & $171-173$ & $171-173$ \\
\hline $5 d$ & & 80 & 86 & 94 & 177 & $176-178$ \\
\hline $5 e$ & & 67 & 73 & 82 & $154-156$ & $155-157$ \\
\hline $5 f$ & & 36 & 60 & 69 & 205 & $204-206$ \\
\hline $5 g$ & & 49 & 66 & 74 & $96-97$ & $95-97$ \\
\hline
\end{tabular}

3.1.2. Ultrasound- and Microwave-Assisted Synthesis of Triazole-Based Benzofuran Derivatives $(\mathbf{7 a}-\mathbf{h})$

Benzofuran-triazole derivatives were synthesized via green synthetic methodologies, namelyultrasound- and microwave-assisted protocols. Benzofuran-triazole derivatives $(7 \mathbf{a}-\mathbf{h})$ were obtained in low to moderate (38-79\%) yields in $36 \mathrm{~h}$ by utilizing conventional methodology [28], while the yield was increased (60-90\%) in the ultrasound-assisted synthetic protocol, in which the scaffold 5-(benzofuran-2-yl)-4-phenyl- $4 H$-1,2,4-triazole3-thiol 6 was coupled with substituted bromoacetanilide derivatives $\mathbf{4 a - h}$ to synthesize corresponding $S$-alkylated benzofuran-triazole derivatives $7 \mathbf{a}-\mathbf{h}$ in good to excellent yield at $40{ }^{\circ} \mathrm{C}$ within $30 \mathrm{~min}$. Similarly, the microwave approach was even more efficient in that 
the $S$-alkylated benzofuran-triazole structural motifs were obtained in maximum yield (68-96\%) within the very short duration of $70 \mathrm{~s}$. The benzofuran-triazole derivative $7 \mathrm{~h}$ was achieved in the maximum yield (90\% and $96 \%$ ) in ultrasound- and microwave-assisted synthetic approaches, while the derivative $7 \mathrm{c}$ was obtained in the least yield $(60 \%$ and $68 \%)$ in ultrasound-assisted andmicrowaveirradiation approaches, as shown in Table 2.

Table 2. Yields of benzofuran-triazole derivatives via conventional, ultrasoundand microwaveassisted synthetic approaches.

\begin{tabular}{|c|c|c|c|c|c|c|}
\hline \multirow[b]{2}{*}{ Compounds } & \multirow[b]{2}{*}{ R-NH } & \multicolumn{3}{|c|}{ Products Percentage Yields } & \multicolumn{2}{|c|}{ m.p. $\left({ }^{\circ} \mathrm{C}\right)$} \\
\hline & & $\begin{array}{c}\text { Conventional } \\
\text { Approach } \\
\text { (Faiz S. et al.) } \\
\text { [29] }\end{array}$ & $\begin{array}{l}\text { Ultrasound- } \\
\text { Assisted } \\
\text { Approach } \\
\text { (This Work) }\end{array}$ & $\begin{array}{l}\text { Microwave- } \\
\text { Assisted } \\
\text { Approach } \\
\text { (This Work) }\end{array}$ & Found & $\begin{array}{c}\text { Reported } \\
\text { (Faiz S. et al.) } \\
\text { [29] }\end{array}$ \\
\hline $7 \mathbf{a}$ & & 73 & 80 & 90 & $220-221$ & $220-222$ \\
\hline $7 \mathrm{~b}$ & & 42 & 64 & 73 & 173-175 & 173-175 \\
\hline $7 \mathrm{c}$ & & 38 & 60 & 68 & $189-190$ & 188-190 \\
\hline $7 \mathrm{~d}$ & & 42 & 63 & 74 & 218-219 & $218-220$ \\
\hline $7 e$ & & 46 & 69 & 77 & $249-251$ & 249-251 \\
\hline $7 \mathrm{f}$ & & 39 & 61 & 70 & $226-227$ & $226-228$ \\
\hline $7 \mathrm{~g}$ & & 64 & 77 & 89 & $229-230$ & $228-230$ \\
\hline
\end{tabular}


Table 2. Cont.

\begin{tabular}{|c|c|c|c|c|c|c|}
\hline \multirow[b]{2}{*}{ Compounds } & \multirow[b]{2}{*}{ R-NH } & \multicolumn{3}{|c|}{ Products Percentage Yields } & \multicolumn{2}{|c|}{ m.p. $\left({ }^{\circ} \mathrm{C}\right)$} \\
\hline & & $\begin{array}{c}\text { Conventional } \\
\text { Approach } \\
\text { (Faiz S. et al.) } \\
\text { [29] }\end{array}$ & $\begin{array}{l}\text { Ultrasound- } \\
\text { Assisted } \\
\text { Approach } \\
\text { (This Work) }\end{array}$ & $\begin{array}{l}\text { Microwave- } \\
\text { Assisted } \\
\text { Approach } \\
\text { (This Work) }\end{array}$ & Found & $\begin{array}{c}\text { Reported } \\
\text { (Faiz S. et al.) } \\
\text { [29] }\end{array}$ \\
\hline $7 \mathrm{~h}$ & & 79 & 90 & 96 & $217-219$ & $216-218$ \\
\hline
\end{tabular}

\subsection{Hemolytic Activity}

Benzofuran-triazole derivative $7 \mathbf{b}$ exhibited the least cytotoxicity $(0.1 \%)$ among all the synthesized derivatives, whereas benzofuran-triazole derivative $7 \mathrm{~g}(23.4 \%)$ and benzofuranoxadiazole $5 \mathrm{~b}(22.12 \%)$ showed the highest toxicity, as depicted in Table 3. Benzofuranoxadiazole $5 \mathbf{d}(5.02 \%), 5 \mathrm{~g}(4.86 \%)$ andbenzofuran-triazole scaffolds such as $\mathbf{7 a}, \mathbf{7 d}$ and $7 \mathbf{f}$ displayed moderate results (6.13-15.7\%). Benzofuran-oxadiazole hybrids $\mathbf{5 a}, \mathbf{5} \mathbf{c}, \mathbf{5 e}$ and 5f showed $0.5-3.7 \%$ hemolysis. The data from Table 3 also demonstrate thatbenzofurantriazole derivatives $7 \mathbf{b}(0.1 \%), 7 \mathbf{c}(2.15 \%)$ and $7 \mathbf{e}(3.11 \%)$ showed the least cytotoxicity among all the benzofuran-triazole derivatives against the positive control. The results demonstrate that the nature and position of the functional groups have a significant effect on the hemolytic potential of synthesized derivatives.

\subsection{Thrombolytic Activity}

All the synthesized analogues were evaluated for thrombolytic potential. Most of the benzofuran-oxadiazole and benzofuran-triazole derivatives displayed a mild to moderate thrombolytic effect when compared with the positive control ABTS. The benzofuran-triazole derivative $7 \mathbf{f}$ showed the highest and best thrombolysis (61.4\%) among all the synthesized hybrids when compared against the reference ABTS. The benzofuran-oxadiazole derivative 5a exhibited significantly good lysis activity (56.8\%) among all the benzofuran-oxadiazole scaffolds. The benzofuran-oxadiazole derivative $5 \mathrm{~g}$ and benzofuran-triazole derivative 7h showed the least lysis (48.3\% and $48.1 \%)$, respectively. Other derivatives such as $5 \mathbf{b}$ $(50.7 \%), 5$ c (52.8\%), 5d (53.5\%), 5e (52.4\%), 5f (56.5\%), 7a (52.2\%), 7b (52.5\%), 7c (54.0\%), 7d (56.2\%), 7e (59.1\%) and $7 \mathbf{g}(49.06 \%)$ showed a mild thrombolytic effect, as described in Table 3. Furthermore, it wasfound that functional groups with a negative inductive effect have a positive influence on thrombolysis.

\subsection{Anticancer Activity}

The cytotoxic perspective of all the synthesized target derivatives $\mathbf{5 a}-\mathbf{g}$ and $\mathbf{7} \mathbf{a}-\mathbf{h}$ was evaluated against lung cancer cell line A549 in comparison with reference standard drugs crizotinib [47-54] and cisplatin [55-60] by determining cell viability usingan MTT assay, as shown in Table 3. The best and most noteworthy cytotoxicity was displayed by benzofuranoxadiazole hybrid $5 \mathbf{d}$, with cell viability $27.49 \pm 1.90$ and $\mathrm{IC}_{50} 6.3 \pm 0.7 \mu \mathrm{M}$, which was lower than the other derivatives. The benzofuran-triazole scaffold $\mathbf{7 h}$ had slightly less cytotoxic potential, with a cell viability of $29.29 \pm 3.98$ and $\mathrm{IC}_{50} 10.9 \pm 0.94 \mu \mathrm{M}$ compared with the derivative $\mathbf{5 d}$. The benzofuran-oxadiazole and triazole derivatives $\mathbf{5 e}, \mathbf{7} \mathbf{d}$ and $7 \mathrm{~g}$, with cell viabilities $34.47 \pm 2.19,39.12 \pm 2.21$ and $36.26 \pm 0.41$, respectively, displayed good inhibition potential against the A549 cancercell line. The benzofuran structural hybrids 5b, 5c, 5f, 5g, 7a, 7c and 7e (cell viability $=45.99 \pm 4.22,43.7 \pm 0.94,43.67 \pm 4.43$, $41.45 \pm 4.10,49.8 \pm 1.06,44.52 \pm 5.01$ and $44.72 \pm 0.84)$ showed moderate anticancer therapeutic potential against lung cancer cells. The target benzofuran derivatives $5 \mathbf{a}$ and $7 \mathbf{b}$ exhibited the least cytotoxic potential, with cell viability $64.1 \pm 1.72$ and $57.62 \pm 4.94$, 
respectively. The benzofuran derivative $\mathbf{7 f}$ was found to be inactive against the A549 lung cancer cell line with a high value of cell viability $(99.1 \pm 5.04)$, as depicted in Table 3.

Table 3. Hemolytic, thrombolytic and anticancer activities of benzofuran-oxadiazole/ triazole derivatives.

\begin{tabular}{|c|c|c|c|c|}
\hline Entry & $\begin{array}{c}\text { Percentage } \\
\text { Hemolysis } \pm \text { SD }\end{array}$ & $\begin{array}{c}\text { Percentage } \\
\text { Thrombolysis } \pm \text { SD }\end{array}$ & $\begin{array}{c}{ }^{\text {a }} \text { Percentage Cell } \\
\text { viability A549 } \\
\text { (Lung Cancer) } \pm \text { SD }\end{array}$ & $\begin{array}{c}\mathrm{IC}_{50}(\mu \mathrm{M}) \\
\text { A549 } \\
\text { (Lung Cancer) }\end{array}$ \\
\hline $5 a$ & $3.7 \pm 0.008$ & $56.8 \pm 0.081$ & $64.1 \pm 1.72$ & - \\
\hline $5 b$ & $22.12 \pm 0.008$ & $50.7 \pm 0.081$ & $45.99 \pm 4.22$ & - \\
\hline $5 c$ & $1.3 \pm 0.008$ & $52.8 \pm 0.081$ & $43.7 \pm 0.94$ & - \\
\hline $5 d$ & $5.02 \pm 0.008$ & $53.5 \pm 0.081$ & $27.49 \pm 1.90$ & $6.3 \pm 0.7$ \\
\hline $5 e$ & $0.5 \pm 0.008$ & $52.4 \pm 0.081$ & $34.47 \pm 2.19$ & $17.9 \pm 0.46$ \\
\hline $5 f$ & $0.74 \pm 0.008$ & $56.5 \pm 0.81$ & $43.67 \pm 4.43$ & - \\
\hline $5 g$ & $4.86 \pm 0.047$ & $48.3 \pm 0.081$ & $41.45 \pm 4.10$ & - \\
\hline $7 a$ & $9.6 \pm 0.081$ & $52.2 \pm 0.081$ & $49.8 \pm 1.06$ & - \\
\hline $7 \mathrm{~b}$ & $0.1 \pm 0.004$ & $52.5 \pm 0.081$ & $57.62 \pm 4.94$ & - \\
\hline $7 \mathrm{c}$ & $2.15 \pm 0.008$ & $54 \pm 0.081$ & $44.52 \pm 5.01$ & - \\
\hline $7 d$ & $6.13 \pm 0.047$ & $56.2 \pm 0.081$ & $39.12 \pm 2.21$ & - \\
\hline $7 e$ & $3.11 \pm 0.008$ & $59.1 \pm 0.008$ & $44.72 \pm 0.84$ & - \\
\hline $7 f$ & $15.7 \pm 0.081$ & $61.4 \pm 0.081$ & $99.1 \pm 5.04$ & - \\
\hline $7 \mathrm{~g}$ & $23.4 \pm 0.081$ & $49.06 \pm 0.047$ & $36.26 \pm 0.41$ & $19.8 \pm 0.54$ \\
\hline $7 \mathrm{~h}$ & $14.8 \pm 0.081$ & $48.1 \pm 0.081$ & $29.29 \pm 3.98$ & $10.9 \pm 0.94$ \\
\hline $\begin{array}{c}\text { ABTS } \\
\text { (+ve control) }\end{array}$ & 95.9 & 86 & - & - \\
\hline $\begin{array}{c}\text { DMSO } \\
\text { (-ve control) }\end{array}$ & - & - & $100 \pm 0$ & - \\
\hline Crizotinib [41-48] & & & $28.22 \pm 3.88$ & $8.54 \pm 0.84$ \\
\hline Cisplatin [49-54] & & & $15.34 \pm 2.98$ & $3.88 \pm 0.76$ \\
\hline
\end{tabular}

${ }^{a}$ Cell viability, $\mathrm{IC}_{50}$ : (Mean $\left.\pm \mathrm{SD}\right)$ in triplicate.

\subsection{Structure-Activity Relationship (SAR)}

The structure-activity relationship ofhemolysis, thrombolysis and the anticancer potential of benzofuran-oxadiazole and triazole hybrids can be interpreted on the basis of substitution patterns present on the phenyl ring of $N$-(substituted-phenyl)-acetamide. The electron-donating ethoxy group atthe para position of the phenyl ring in benzofuranoxadiazole compound 5 e showed $0.5 \%$ toxicity against RBCs, whereas benzofuran-triazole derivative $7 \mathbf{b}$ exhibited $0.1 \%$ toxicity, which was significantly lower than the other derivatives. On the other hand, compounds $5 \mathrm{~b}$ and $7 \mathrm{~g}(22.12 \%$ and $23.4 \%)$ proved to be the most toxic compounds among the benzofuran-oxadiazole and benzofuran-triazole series, respectively (Figure 4a). 


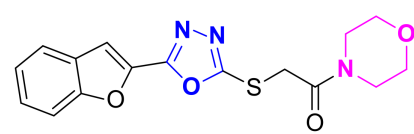

$5 b$

Hemolysis $=22.12 \pm 0.008 \%$<smiles>O=C(CSc1nnc(-c2cc3ccccc3o2)n1-c1ccccc1)Nc1ccc(Cl)cc1</smiles>

$7 g$

Hemolysis $=23.4 \pm 0.081 \%$

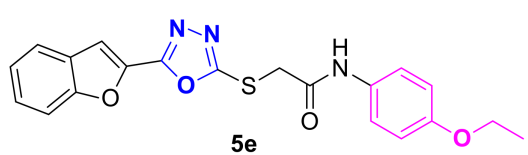

Hemolysis $=0.5 \pm 0.008 \%$

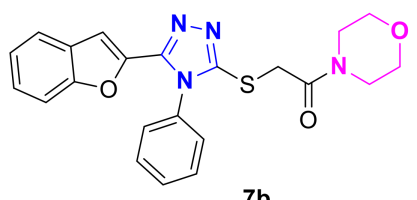

Hemolysis $=0.1 \pm 0.004 \%$

(a)

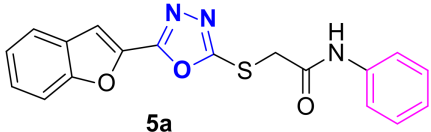

Thrombolysis $=\mathbf{5 6 . 8} \pm \mathbf{0 . 0 8 1} \%$

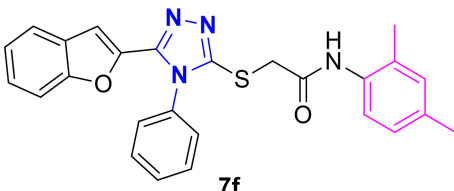

Thrombolysis $=61.4 \pm 0.081 \%$

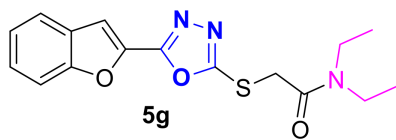

Thrombolysis $=\mathbf{4 8 . 3} \pm \mathbf{0 . 0 8 1} \%$

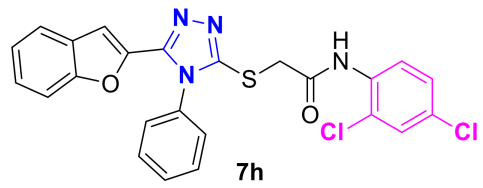

Thrombolysis $=\mathbf{4 8 . 1 \pm 0 . 0 8 1 \%}$

(b)

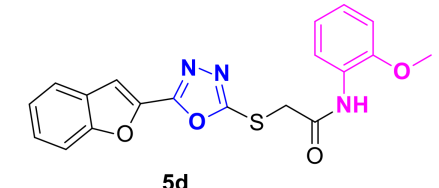

Anticancer agent $=27.49 \pm 1.90 \%$ cell viability $\mathrm{IC}_{50}=6.3 \pm 0.7 \mu \mathrm{M}$

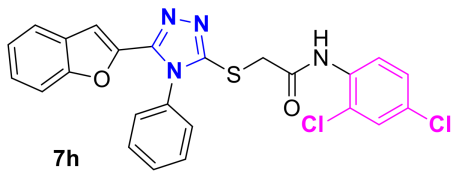

Anticancer agent $=\mathbf{2 9 . 2 9} \pm \mathbf{3 . 9 8} \%$ cell viability $\mathrm{IC}_{50}=10.9 \pm 0.94 \mu \mathrm{M}$

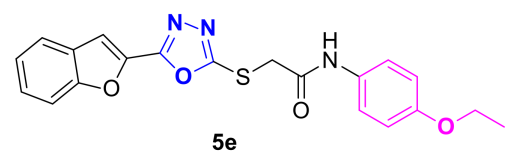

Anticancer agent $=34.47 \pm 2.19 \%$ cell viability ${ }^{\prime C} C_{50}=17.9 \pm 0.46 \mu \mathrm{M}$

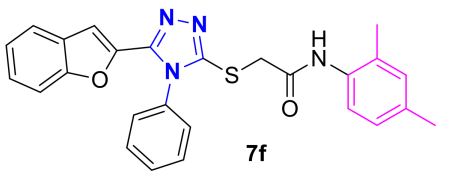

Inactive agent $=99.1 \pm 5.04 \%$ cell viability

(c)

Figure 4. (a) Structure-activity relationship of hemolytic compounds $5 \mathbf{b}, 5 \mathbf{e}, 7 \mathrm{~g}$ and $7 \mathbf{b}$. (b) Structureactivity relationship of thrombolytic compounds $5 \mathbf{a}, 5 \mathrm{~g}, \mathbf{7 f}$ and $\mathbf{7 h}$. (c) Structure-activity relationship of anticancer $5 \mathrm{~d}, 5 \mathrm{e}, 7 \mathrm{~h}$ and $7 \mathrm{f}$ derivatives. 
In the case of thrombolytic activity, the benzofuran-oxadiazole scaffold 5a with unsubstituted phenyl displayed better thrombolytic potential $(56.8 \%)$ compared withdiethyl amine moiety containing the $5 \mathrm{~g}$ benzofuran-oxadiazole hybrid. The phenyl group increased the thrombolytic potential of $\mathbf{5 a}$, while the diethylamine resulted in a decrease in thrombolytic activity (48.3\%) of the $\mathbf{5 g}$ hybrid. The benzofuran-triazole hybrid $\mathbf{7 f}$ was the most active thrombolytic agent among all the screened derivatives of benzofuranoxadiazole and benzofuran-triazole, displaying the highest thrombolysis potential (61.4\%) due to the presence of two methyl groups adjacently attached on the phenyl ring at ortho para positions. The benzofuran derivative $7 \mathrm{~h}$ showed the least thrombolytic potential (48.1\%) compared with all thetested compounds. The thrombolysis activity of 7 h was significantly decreased due to the presence of two chloro EWD groups adjacently attached on the phenyl ring at the ortho and para positions, as depicted in Figure $4 \mathrm{~b}$.

The benzofuran-oxadiazole derivative $5 \mathbf{d}$ exhibited excellent anticancer activity (cell viability $27.49 \pm 1.90 \%$ and $\mathrm{IC}_{50} 6.3 \pm 0.7 \mu \mathrm{M}$ ) compared withall the screened derivatives, due to the presence of a methoxy group at the meta position on the phenyl ring;because of the presence of the ethoxy group at the para position on the phenyl ring, however, the benzofuran-oxadiazole derivative $\mathbf{5 e}$ displayedmoderate anticancer activity (cell viability $34.47 \pm 2.19 \%$ and $\mathrm{IC}_{50} 17.9 \pm 0.46 \mu \mathrm{M}$ ) in comparison with the reference drugs crizotinib and cisplatin $(28.22 \pm 3.88$ and $15.34 \pm 2.98 \mu \mathrm{M})$, respectively. The structural hybrid $\mathbf{5 d}$ is more potent than crizitonib and showed less cytotoxic potential than cisplatin. Due to the presence of two chloro EWD groups adjacently attached on the phenyl ring at the ortho and para positions, benzofuran-triazole scaffold $7 \mathrm{~h}$ exhibited slightly less potency (cell viability $29.29 \pm 3.98 \%$ and $\mathrm{IC}_{50} 10.9 \pm 0.94 \mu \mathrm{M}$ ) against lung cancer cell line A549 compared with 5d scaffold, which was the most active compound among all the screened derivatives. The benzofuran-triazole hybrid $7 \mathbf{f}$ was an inactive compound (cell viability $99.1 \%$ ) against the A549 cell line due to the presence of two methyl groups adjacently attached on the phenyl ring at the ortho and para positions (Figure $4 \mathrm{c}$ ).

\subsection{Computational Modeling Studies of the Most Active Compound $\mathbf{5 d}$}

The synthesized compound $\mathbf{5 d}(\mathbf{B})$ and co-crystallized ligand crizotinib were docked against the anaplastic lymphoma kinase (ALK) receptors to understand better the mechanisms of attachment and inhibition. The compound-docked conformations were interpreted by binding interactions, energies, polar bonding and ligand-receptor binding.

The molecular comprehension of docking experimentssuggest that compound $\mathbf{5 d}$ (B) is more prominent as it produces excellent results with binding energies of -9.925 $\mathrm{Kcal} / \mathrm{mol}$ in the best binding mode. This exceeds the average energy threshold of -8.985 $\mathrm{Kcal} / \mathrm{mol}$ given by crizotinib, thereby commending the improved affinity of synthesized compound 5d (B) against the ALK receptor (Table 4).

Table 4. Molecular docking parameters analysis against ALK receptors.

\begin{tabular}{|c|c|c|c|c|c|}
\hline Target & Ligand & $\begin{array}{l}\text { Binding Energies } \\
\text { (Kcal/mol) }\end{array}$ & Binding Residues & Type of Interaction & $\begin{array}{l}\text { Bond Distance } \\
\text { Range (Å) }\end{array}$ \\
\hline \multirow{2}{*}{$\begin{array}{c}\text { Anaplastic } \\
\text { lymphoma kinase } \\
(\mathrm{ALK}) \text { receptors }\end{array}$} & Crizotinib & -8.985 & $\begin{array}{l}\text { LEU A: 1122, ALA } \\
\text { A: 1148, MET A: } \\
\text { 1199, GLU A: 1197, } \\
\text { ARG A: } 1253, \text { LEU } \\
\text { A: } 1256\end{array}$ & $\begin{array}{l}\text { Conventional hydrogen } \\
\text { bond, carbon hydrogen } \\
\text { bond, pi-sigma, alkyl } \\
\text { interaction, pi-alkyl, van } \\
\text { der Waals interactions }\end{array}$ & $2.98-4.48$ \\
\hline & Compound 5d & -9.925 & $\begin{array}{c}\text { VAL A: 1130, ALA } \\
\text { A: 1148, GLY A: } \\
\text { 1201, ASP A: 1203, } \\
\text { GLU A: 1210, LEU } \\
\text { A: 1256, PRO A: } \\
1260\end{array}$ & $\begin{array}{l}\text { Conventional hydrogen } \\
\text { bond, pi-anion, pi-donor } \\
\text { hydrogen bond, pi-sigma, } \\
\text { pi-alkyl, van der Waals } \\
\text { interactions }\end{array}$ & $2.68-4.57$ \\
\hline
\end{tabular}


The active binding site of an ALK receptor prominently consists of ALA: 1252, ARG: 1253, ASN: 1254, CYS: 1255, LEU: 1256, LEU: 1257, THR: 1258, CYS: 1259 and PRO: 1260. Crizotinib was found to have noticeable contacts with these active site residues, but compound $\mathbf{5 d}$ (B) displayed more effective binding at these active amino acid AA residues, representing more effective working of this synthesized chemical moiety. The binding of compound 5d (B) and crizotinib with receptors are elaborated in Figure 5. The phenyl and heterocyclic rings of compound $5 \mathbf{d}(\mathbf{B})$ showed $\pi$-sigma interaction with LEU A: 1256 and VAL A: 1130, while the NH group gave conventional hydrogen bonds with GLY A: 1201. Another prominent interaction appeared with GLU A: 1210 through $\pi$-anion linkage.
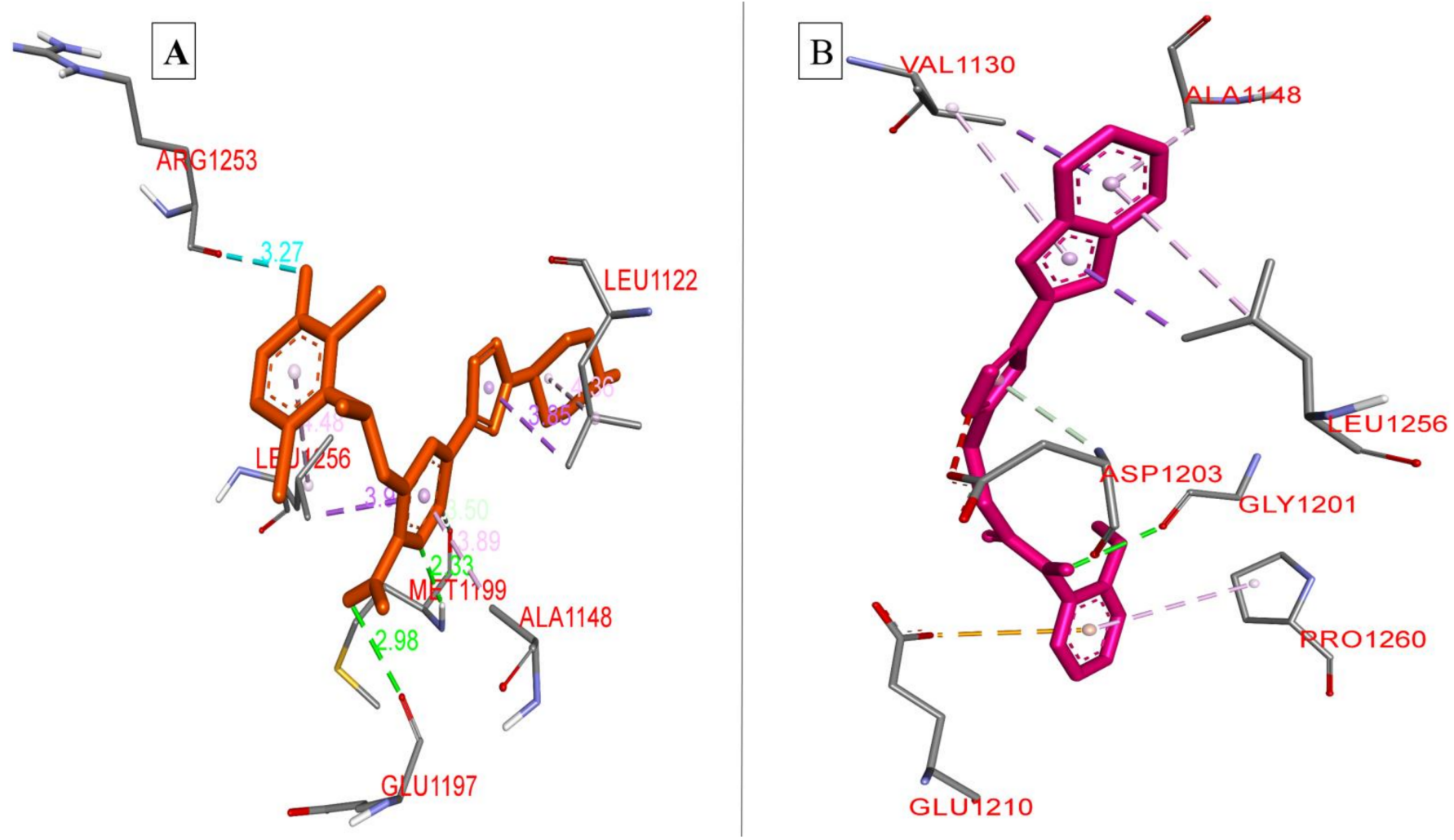

Figure 5. (A) 3D Model of crizotinib (brown) inside the bonding pocket of protein with interactions shown; (B) 3D model of compound 5d (pink) with all atoms shown, collaborating with amino acid residues with bond distances displayed.

Compound $\mathbf{5 d}(\mathbf{B})$ was docked to determine its interaction with the subject protein and exhibited interesting results. It gave the negative binding energies of $-9.925 \mathrm{Kcal} / \mathrm{mol}$ in its best binding mode. The prominent amino acid residues were VAL A: 1130, ALA A: 1148, GLY A: 1201, ASP A: 1203, GLU A: 1210, LEU A: 1256 and PRO A: 1260, as shown in Figure 6. 

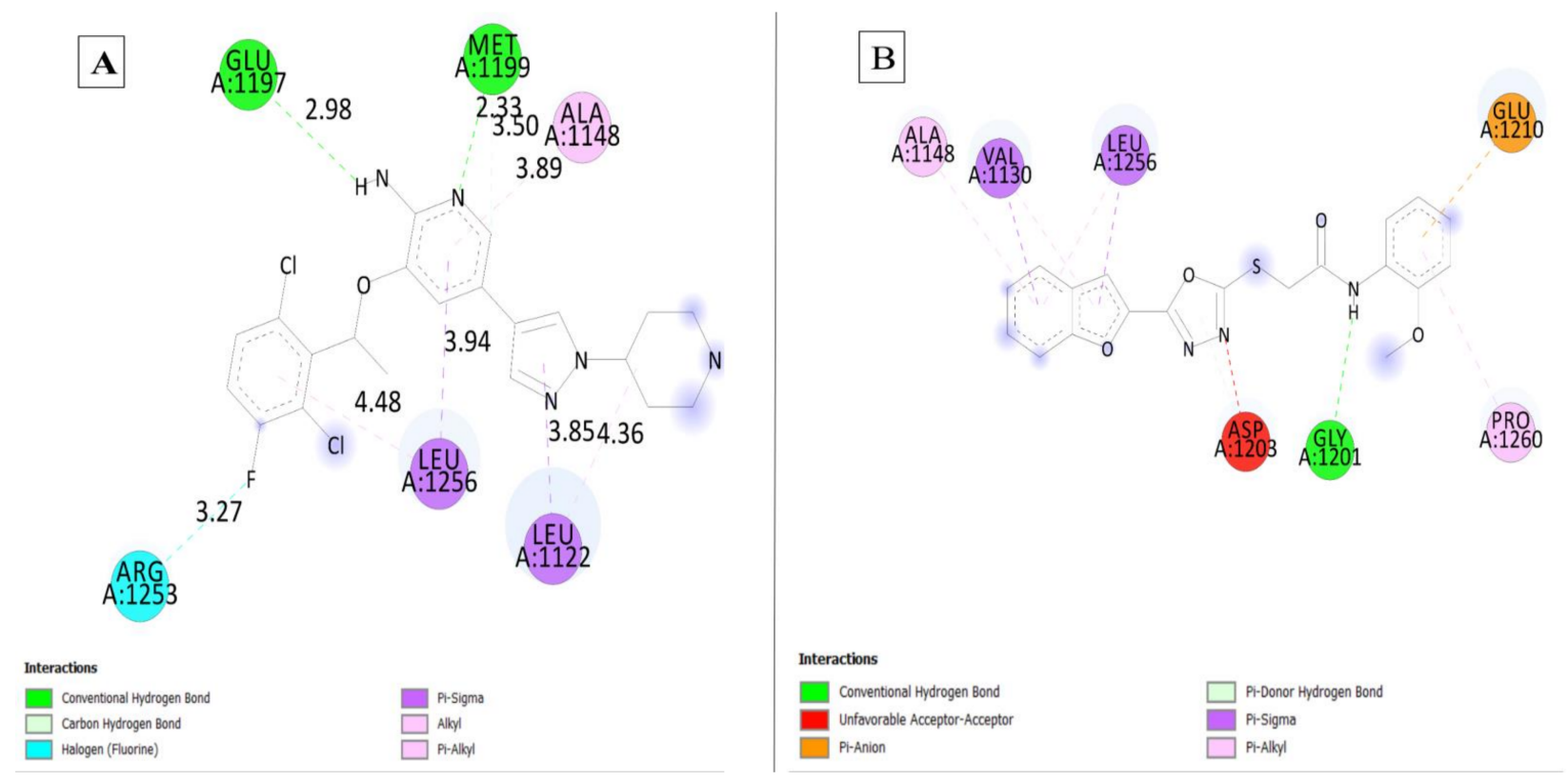

Figure 6. (A) 2D Model of crizotinib inside the bonding pocket of protein with interactions shown; (B) 2D model of compound 5d (B) with all atoms shown, collaborating with amino acid residues with bond distances displayed.

Evaluation through docking studies provides good evidence that synthesized compound $5 \mathbf{d}$ presents excellent interaction inside the binding pocket of a receptor, showing its better anticancer potential as compared withthe co-crystallized ligand crizotinib. These computational studies are reliable and appropriate for performing binding interaction prediction. The conformational analysis revealed thespatial arrangement of compound $5 \mathrm{~d}$, justifying it to be more potent, in comparison with crizotinib. Interestingly, compound $\mathbf{5 d}$ interactions were more realistic, with better results. Therefore, scaffold $\mathbf{5 d}$ would be a promising anticancer agent on the basis of both cytotoxicity and in silico studies.

\section{Conclusions}

The target S-alkylated structural motifs of benzofuran-oxadiazole and -triazole were synthesized in good to excellent yields by utilizing ultrasound- and microwave-assisted green synthetic protocols. The compounds were evaluated for anticancer, hemolytic and thrombolytic activities, and it wasrevealed that most of tested derivatives displayed significant hemolytic, thrombolytic and anticancer activities. The hemolysis assay indicated that benzofuran-triazole derivative $7 \mathbf{b}$ and benzofuran-oxadiazole $5 e$ proved to be the least toxic compounds among all the synthesized derivatives. The benzofuran-oxadiazole hybrid $\mathbf{5 d}$ with cell viability $27.49 \pm 1.90$ and $\mathrm{IC}_{50}(6.3 \pm 0.7 \mu \mathrm{M})$ values was recognized as the most potent anticancer candidate against lung cancer cell line A549 compared with the reference drugs crizotinib $\left(\mathrm{IC}_{50} 8.54 \pm 0.84 \mu \mathrm{M}\right)$ and cisplatin with $\left(\mathrm{IC}_{50} 3.88 \pm 0.76 \mu \mathrm{M}\right)$. The docking studies explored the mode of action and inhibition mechanism of compound $\mathbf{5 d}$ againstcancer cells; the results of the comprehensive docking analysis of compound $\mathbf{5 d}$ are consistent and in agreement with biological diagnostic findings. Overall, the current studies suggest that benzofuran-linked oxadiazole and triazole hybrids are capable of being established as lead compounds in cancer therapy; in particular, scaffold $\mathbf{5 d}$ could be a promising anticancer agent on the basis of cytotoxicity andin silico studies. The SAR studies suggested that more modifications to oxadiazole and triazole derivatives of benzofuran may lead to advanced anticancer candidates in cancer therapy.

Author Contributions: Conceptualization: A.F.Z.; biological research: A.R.; docking studies; R.Z.; synthesis: A.I.; literature collection and analysis: S.F.; writing-original draft preparation: A.I. 
and S.F.; writing - review and editing: K.K.-M. and M.M. All authors have read and agreed to the published version of the manuscript.

Funding: This research received no external funding.

Institutional Review Board Statement: Not Applicable.

Informed Consent Statement: Not Applicable.

Data Availability Statement: Not Applicable.

Acknowledgments: The authors are thankful for and acknowledge the Government College University Faisalabad, Pakistan for providing research facilities to carry out this research.

Conflicts of Interest: The authors declare no conflict of interest.

Sample Availability: Samples of the compounds are available from the authors.

\section{References}

1. Napiórkowska, M.; Cieślak, M.; Barańska, K.J.; Golińska, K.K.; Nawrot, B. Synthesis of new derivatives of benzofuran as potential anticancer agents. Molecules 2019, 24, 1529. [CrossRef] [PubMed]

2. Aslam, S.N.; Stevenson, P.C.; Phythian, S.J.; Veitch, N.C.; Hall, D.R. Synthesis of cicerfuran, an antifungal benzofuran, and some related analogues. Tetrahedron 2006, 62, 4214-4226. [CrossRef]

3. Clive, D.L.J.; Stoffman, E.J.L. Total synthesis of (-)-conocarpan and assignment of the absolute configuration by chemical methods. Chem. Commun. 2007, 21, 2151-2153. [CrossRef] [PubMed]

4. Naik, R.; Harmalkar, S.D.; Xu, X.; Jang, K.; Lee, K. Bioactive benzofuran derivatives: Moracins AeZ in medicinal chemistry. Eur. J. Med. Chem. 2015, 90, 379-393. [CrossRef] [PubMed]

5. Rangaswamy, J.; Kumar, H.V.; Harini, S.T.; Naik, N. Functionalized 3-(benzofuran-2-yl)-5-(4-methoxyphenyl)-4,5-dihydro-1Hpyrazole scaffolds: A new class of antimicrobials and antioxidants. Arab. J. Chem. 2017, 10, S2685-S2696. [CrossRef]

6. $\quad$ Romagnoli, R.; Baraldi, G.P.; Sarkar, T.; Cara, L.C.; Lopez, C.O.; Carrion, D.M.; Preti, D.; Tolomeo, M.; Balzarini, J.; Hamel, E Synthesis and biological evaluation of 2-aroyl-4-phenyl-5- hydroxybenzofurans as a new class of anti-tubulin agents. Med. Chem. 2008, 4, 558-564. [CrossRef]

7. Zeni, G.; Ludtke, D.S.; Nogueira, C.W.; Panatieri, R.B.; Antonio, L.; Braga, A.L.; Silveira, C.C.; Stefanib, A.H.; Rochaa, J.B. New acetylenic furan derivatives: Synthesis and anti-inflammatory activity. Tetrahedron Lett. 2001, 42, 8927-8930. [CrossRef]

8. Matsuya, Y.; Sasaki, K.; Nagaoka, M.; Kakuda, H.; Toyooka, N.; Imanishi, N.; Ochiai, H.; Nemoto, H. Synthesis of a new class of furan-fused tetracyclic compounds using o-quinodimethane chemistry and investigation of their antiviral activity. J. Org. Chem. 2004, 69, 7989-7993. [CrossRef]

9. Singh, F.V.; Chaurasia, S.; Joshi, M.D.; Srivastava, A.K.; Goel, A. Synthesis and in vivo antihyperglycemic activity of naturemimicking furanyl-2-pyranones in STZ-S model. Bioorg. Med. Chem. Lett. 2007, 17, 2425-2429. [CrossRef]

10. Farag, A.A.; El Shehry, F.M.; Abbas, S.Y.; Abd-Alrahman, S.N.; Atrees, A.A.; Al-basheer, H.Z.; Ammar, Y.A. Synthesis of pyrazoles containing benzofuran and trifluoromethyl moieties as possible anti-inflammatory and analgesic agents. Z. Nat. B 2015, 70, 519-526. [CrossRef]

11. Lu, D.; Zhou, Y.; Li, Q.; Luo, J.; Jiang, Q.; He, B.; Tang, Q. Synthesis, in vitro antitumor activity and molecular mechanism of novel furan derivatives and their precursors. Anticancer Agents Med. Chem. 2020, 20, 1475-1486. [CrossRef]

12. Islam, K.; Pal, K.; Debnath, U.; Basha, R.S.; Khan, A.T.; Jana, K.; Misra, A.K. Anti-cancer potential of (1,2-dihydronaphtho[2,1b]furan-2-yl)methanone derivatives. Bioorg. Med. Chem. Lett. 2020, 30, 127476. [CrossRef] [PubMed]

13. Tighadouini, S.; Radi, S.; Benabbes, R.; Youssoufi, M.H.; Shityakov, S.; El Massaoudi, M.; Garcia, Y. Synthesis, biochemical characterization, and theoretical studies of novel $\beta$-keto-enol pyridine and furan derivatives as potent antifungal agents. ACS Omega 2020, 5, 17743-17752. [CrossRef] [PubMed]

14. Xie, Y.-S.; Kumar, D.; Bodduri, V.V.; Tarani, P.S.; Zhao, B.-X.; Miao, J.-Y.; Jang, K.; Shin, D.-S. Microwave-assisted parallel synthesis of benzofuran-2-carboxamide derivatives bearing anti-inflammatory, analgesic and antipyretic agents. Tetrahedron Lett. 2014, 55, 2796-2800. [CrossRef]

15. Dong, Y.; Shi, Q.; Liu, Y.-N.; Wang, X.; Bastow, K.F.; Lee, K.-H. Antitumor Agents. 266. Design, Synthesis, and Biological Evaluation of Novel 2-(Furan-2-yl)naphthalen-1-ol Derivatives as Potent and Selective Antibreast Cancer Agents. J. Med. Chem. 2009, 52, 3586-3590. [CrossRef] [PubMed]

16. Miao, Y.; Hu, Y.; Yang, J.; Liu, T.; Sun, J.; Wang, X. Natural source, bioactivity and synthesis of benzofuran derivatives. RSC Adv. 2019, 9, 27510-27540. [CrossRef]

17. $\mathrm{Xu}, \mathrm{Z}$.; Zhao, S.J.; Liu, Y. 1,2,3-Triazole-containing hybrids as potential anticancer agents: Current developments, action mechanisms and structure-activity relationships. Eur. J. Med. Chem. 2019, 183, 111700. [CrossRef]

18. Kapoor, G.; Bhutani, R.; Pathak, D.P.; Chauhan, G.; Kant, R.; Grover, P.; Siddiqui, S.A. Current Advancement in the OxadiazoleBased Scaffolds as Anticancer Agents. Polycycl. Aromat. Compd. 2021, in press. [CrossRef] 
19. Irfan, A.; Ullah, S.; Anum, A.; Jabeen, N.; Zahoor, F.A.; Kanwal, H.; Kotwica-Mojzych, K.; Mojzych, M. Synthetic transformations and medicinal significance of 1,2,3-thiadiazoles derivatives: An update. Appl. Sci. 2021, 11, 5742. [CrossRef]

20. Shahzadi, I.; Zahoor, A.F.; Rasul, A.; Mansha, A.; Ahmad, S.; Raza, Z. Synthesis, hemolytic studies, and in silico modeling of novel acefylline-1,2,4-triazole hybrids as potential anti-cancer agents against MCF-7 and A549. ACS Omega 2021, 6, 11943-11953. [CrossRef]

21. Irfan, A.; Batool, F.; Naqvi, Z.A.S.; Islam, A.; Osman, M.S.; Nocentini, A.; Alissa, A.S.; Supuran, T.C. Benzothiazole derivatives as anticancer agents. J. Enzyme Inhib. Med. Chem. 2020, 35, 265-279. [CrossRef] [PubMed]

22. Van Miert, S.; Van Dyck, S.; Schmidt, T.J.; Brun, R.; Vlietinck, A.; Lemiere, G.; Pieters, L. Antileishmanial activity, cytotoxicity and QSAR analysis of synthetic dihydrobenzofuran lignans and related benzofurans. Bioorg. Med. Chem. 2005, 13, 661-669. [CrossRef] [PubMed]

23. Zhang, G.N.; Zhong, L.Y.; Bligh, S.W.A.; Guo, Y.L.; Zhang, C.F.; Zhang, M.; Wang, Z.T.; Xu, L.S. Bi-bicyclic and bi-tricyclic compounds from Dendrobiumthyrsiflorum. Phytochemistry 2005, 66, 1113-1120. [CrossRef] [PubMed]

24. Murthy, I.S.; Sireesha, R.; Deepthi, K.; Rao, P.S.; Raju, R.R. Design, synthesis and biological evaluation of sulphonamide derivatives of benzofuran-imidazopyridines as anticancer agents. Chem. Data Collect. 2020, 31, 100608. [CrossRef]

25. Mokenapelli, S.; Thalari, G.; Vadiyaala, N.; Yerrabelli, J.R.; Irlapati, V.K.; Gorityala, N.; Sagurthi, S.R.; Chitneni, P.R. Synthesis, cytotoxicity, and molecular docking of substituted 3-(2-methylbenzofuran-3-yl)-5-(phenoxymethyl)-1,2,4-oxadiazoles. Arch. Pharm. 2020, 353, e2000006. [CrossRef]

26. Mphahlele, M.J.; Maluleka, M.M.; Aro, A.; McGaw, L.J.; Choong, Y.S. Benzofuran-appended 4-aminoquinazoline hybrids as epidermal growth factor receptor tyrosine kinase inhibitors: Synthesis, biological evaluation and molecular docking studies. $J$. Enzyme Inhib. Med. Chem. 2018, 33, 1516-1528. [CrossRef] [PubMed]

27. Eldehna, W.M.; Nocentini, A.; Elsayed, Z.M.; Al-Warhi, T.; Aljaeed, N.; Alotaibi, O.J.; Al-Sanea, M.M.; Abdel-Aziz, H.A.; Supuran, C.T. Benzofuran-based carboxylic acids as carbonic anhydrase inhibitors and antiproliferative agents against breast cancer. ACS Med. Chem. Lett. 2020, 11, 1022-1027. [CrossRef]

28. Othman, D.I.; Abdelal, A.M.; El-Sayed, M.; El Bialy, S.A.A. Novel benzofuran derivatives: Synthesis and antitumor activity. Heterocycl. Commun. 2013, 19, 29-35. [CrossRef]

29. Faiz, S.; Zahoor, A.F.; Ajmal, M.; Kamal, S.; Ahmad, S.; Abdelgawad, A.M.; Elnaggar, E.M. Design, synthesis, antimicrobial evaluation, and laccase catalysis effect of novel benzofuran-oxadiazole and benzofuran-triazole hybrids. J. Heterocycl. Chem. 2019, 56, 2839-2852. [CrossRef]

30. Shi, Z.; Zhao, Z.; Huang, M.; Fu, X. Ultrasound-assisted, one-pot, three-component synthesis and antibacterial activities of novel indole derivatives containing 1,3,4-oxadiazole and 1,2,4-triazole moieties. C. R. Chim. 2015, 18, 1320-1327. [CrossRef]

31. Virk, N.A.; Rehman, A.; Abbasi, M.A.; Siddiqui, S.Z.; Rashid, U.; Iqbal, J.; Saleem, M.; Ashraf, M.; Shahid, W.; Shah, S.A.A Conventional versus microwave assisted synthesis, molecular docking and enzyme inhibitory activities of new 3,4,5-trisubstituted1,2,4-triazole analogues. Pak. J. Pharm. Sci. 2018, 31, 1501-1510. [PubMed]

32. Javid, J.; Rehman, A.; Abbasi, M.A.; Siddiqui, S.Z.; Iqbal, J.; Virk, N.A.; Rasool, S.; Ali, H.A.; Ashraf, M.; Shahid, W.; et al. Comparative conventional and microwave assisted synthesis of heterocyclic oxadiazole analogues having enzymatic inhibition potential. J. Heterocycl. Chem. 2021, 58, 93-110. [CrossRef]

33. Virk, N.A.; Rehman, A.; Abbasi, M.A.; Siddiqui, S.Z.; Iqbal, J.; Rasool, S.; Khan, S.U.; Htar, T.T.; Khalid, H.; Lauloo, S.J.; et al. Microwave-assisted synthesis of triazole derivatives conjugated with piperidine as new anti-enzymatic agents. J. Heterocycl. Chem. 2020, 57, 1387-1402. [CrossRef]

34. Sapkal, S.B.; Shelke, K.F.; Shingate, B.B.; Shingare, M.S. An efficient synthesis of benzofuran derivatives under conventional/nonconventional method. Chin. Chem. Lett. 2010, 21, 1439-1442. [CrossRef]

35. Vani, I.; Sireesha, R.; Mak, K.; Rao, P.M.; Prasad, K.R.S.; Rao, M.V.B. Microwave assisted synthesis and antimicrobial and antioxidant activities of dimers of 1,2,3-triazole-benzofuran bearing alkyl spacer derivatives. Chem. Data Collect. 2020, 31,100605 [CrossRef]

36. Reddy, E.R.; Ramesh, S.; Anitha, K.; Reddy, A.P.; Reddy, V.P. Microwave-assisted synthesis and antibacterial activity of 1-(5-((2-(4bromobenzoyl)-3-methylbenzofuran-5-yl)methyl)-2-((1-aryl-1H-1,2,3-triazol-4-yl)methoxy)phenyl)ethanones. Chem. Data Collect. 2021, 34, 100730. [CrossRef]

37. Ashok, D.; Gandhi, D.M.; Srinivas, G.; Kumar, A.V. Microwave-assisted synthesis of novel 1,2,3-triazole derivatives and their antimicrobial activity. Med. Chem. Res. 2014, 23, 3005-3018. [CrossRef]

38. Farshori, N.N.; Rauf, A.; Siddiqui, M.A.; Al-Sheddi, E.S.; Al-Oqail, M.M. A facile one-pot synthesis of novel 2,5-disubstituted1,3,4-oxadiazoles under conventional and microwave conditions and evaluation of their in vitro antimicrobial activities. Arab. J. Chem. 2017, 10, S2853-S2861. [CrossRef]

39. Jaisankar, K.R.; Kumaran, K.; Kamil, S.R.M.; Srinivasan, T. Microwave-assisted synthesis of 1,2,4-triazole-3-carboxamides from esters and amines under neutral conditions. Res. Chem. Intermed. 2015, 41, 1975-1984. [CrossRef]

40. Riaz, M.; Rasool, N.; Bukhari, I.; Shahid, M.; Zubair, M.; Rizwan, K.; Rashid, U. In vitro antimicrobial, antioxidant, cytotoxicity and GC-MS analysis of Mazus goodenifolius. Molecules 2012, 17, 14275-14287. [CrossRef]

41. Batool, M.; Tajammal, A.; Farhat, F.; Verpoort, F.; Khattak, Z.A.K.; Mehr-un-Nisa, M.S.; Ahmad, H.A.; Munawar, M.A.; Ziaur-Rehman, M.; Basra, M.A.R. Molecular Docking, Computational, and Antithrombotic Studies of Novel 1, 3, 4-Oxadiazole Derivatives. Int. J. Mol. Sci. 2018, 19, 3606. [CrossRef] [PubMed] 
42. Rasul, A.; Di, J.; Millimouno, F.; Malhi, M.; Tsuji, I.; Ali, M.; Li, J.; Li, X. Reactive oxygen species mediate isoalantolactone-induced apoptosis in human prostate cancer cells. Molecules 2013, 18, 9382-9396. [CrossRef] [PubMed]

43. Arun, Y.; Saranraj, K.; Balachandran, C.; Perumal, P.T. Novel spirooxindole-pyrrolidine compounds: Synthesis, anticancer and molecular docking studies. Eur. J. Med. Chem. 2014, 74, 50-64. [CrossRef] [PubMed]

44. Mustafa, M.; Abdelhamid, D.; Abdelhafez, E.M.; Ibrahim, M.A.; Gamal-Eldeen, A.M.; Aly, O.M. Synthesis, antiproliferative, anti-tubulin activity, and docking study of new 1,2,4-triazoles as potential combretastatin analogues. Eur. J. Med. Chem. 2017, 141, 293-305. [CrossRef] [PubMed]

45. Saidi, I.; Nimbarte, V.D.; Schwalbe, H.; Waffo-Téguo, P.; Harrath, A.H.; Mansour, L.; Jannet, H.B. Anti-tyrosinase, anticholinesterase and cytotoxic activities of extracts and phytochemicals from the Tunisian Citharexylum spinosum L.: Molecular docking and SAR analysis. Bioorg.Chem. 2020, 102, 104093. [CrossRef]

46. Lakshmanan, S.; Govindaraj, D.; Ramalakshmi, N.; Antony, S.A. Synthesis, molecular docking, DFT calculations and cytotoxicity activity of benzo [g] quinazoline derivatives in choline chloride-urea. J. Mol. Struct. 2017, 1150, 88-95. [CrossRef]

47. Bang, Y.-J. The potential for crizotinib in non-small cell lung cancer: A perspective review. Ther. Adv. Med. Oncol. 2011, 3, $279-291$. [CrossRef]

48. Dai, X.; Guo, G.; Zou, P.; Cui, R.; Chen, W.; Chen, X.; Yin, C.; He, W.; Vinothkumar, R.; Yang, F.; et al. (S)-crizotinib induces apoptosis in human non-small cell lung cancer cells by activating ROS independent of MTH1. J. Exp. Clin. Cancer Res. 2017, 36, 120. [CrossRef] [PubMed]

49. Chuang, J.C.; Neal, J.W. Crizotinib as first line therapy for advanced ALK-positive non-small cell lung cancers. Transl. Lung Cancer Res. 2015, 4, 639-641. [CrossRef]

50. Chen, R.L.; Zhao, J.; Zhang, X.C.; Lou, N.N.; Chen, H.J.; Yang, X.; Su, J.; Xei, Z.; Zhou, O.; Tu, H.Y.; et al. Crizotinib in advanced non-small-cell lung cancer with concomitant $A L K$ rearrangement and c-Met overexpression. BMC Cancer 2018, 18, 1171. [CrossRef]

51. Roberts, P.J. Clinical use of crizotinib for the treatment of non-small cell lung cancer. Biol. Targets Ther. 2013, 7, 91-101. [CrossRef] [PubMed]

52. Liu, C.; Yu, H.; Long, Q.; Chen, H.; Li, Y.; Zhao, W.; Zhao, K.; Zhu, Z.; Sun, S.; Fan, M.; et al. Real world experience of crizotinib in 104 patients with alk rearrangement non-small-cell lung cancer in a single chinese cancer center. Front. Oncol. 2019, 9, 1116. [CrossRef] [PubMed]

53. Wang, Q.; He, Y.; Yang, X.; Wang, Y.; Xiao, H. Extraordinary response to crizotinib in a woman with squamous cell lung cancer after two courses of failed chemotherapy. BMC Pulm. Med. 2014, 14, 83. [CrossRef] [PubMed]

54. Drilon, A.; Clark, J.W.; Weiss, J.; Ou, S.-H.I.; Camidge, D.R.; Solomon, B.J.; Otterson, G.A.; Villaruz, L.C.; Riely, G.J.; Heist, R.S.; et al. Antitumor activity of crizotinib in lung cancers harboring a MET exon 14 alteration. Nat. Med. 2020, 26, 47-51. [CrossRef] [PubMed]

55. Ma, Y.; Zheng, X.; Gao, H.; Wan, C.; Rao, G.; Mao, Z. Design, synthesis, and biological evaluation of novel benzofuran derivatives bearing $n$-aryl piperazine moiety. Molecules 2016, 21, 1684. [CrossRef]

56. Tseng, C.-Y.; Lin, C.-H.; Wu, L.-Y.; Wang, J.-S.; Chung, M.-C.; Chang, J.-F.; Chao, M.-W. Potential combinational anti-cancer therapy in non-small cell lung cancer with traditional chinese medicine sun-bai-pi extract and cisplatin. PLoS ONE 2016, 11, e0155469. [CrossRef]

57. Ozturk, O.H.; Bozcuk, H.; Burgucu, D.; Ekinci, D.; Ozdogan, M.; Akca, S.; Yildiz, M. Cisplatin cytotoxicity is enhanced with zoledronic acid in A549 lung cancer cell line: Preliminary results of an in vitro study. Cell Biol. Int. 2007, 31, 1069-1071. [CrossRef]

58. .Ahmed, F.F.; Abd El-Hafeez, A.A.; Abbas, S.H.; Abdelhamid, D.; Abdel-Aziz, M. New 1,2,4-triazole-Chalcone hybrids induce Caspase-3 dependent apoptosis in A549 human lung adenocarcinoma cells. Eur. J. Med. Chem. 2018, 151, 705-722. [CrossRef]

59. Özdemir, A.; Sever, B.; Altıntop, M.D.; Temel, H.E.; Atlı, Ö.; Baysal, M.; Demirci, F. Synthesis and Evaluation of New Oxadiazole, Thiadiazole, and Triazole Derivatives as Potential Anticancer Agents Targeting MMP-9. Molecules 2017, 22, 1109. [CrossRef]

60. Wagner, E.; Wietrzyk, J.; Psurski, M.; Becan, L.; Turlej, E. Synthesis and Anticancer Evaluation of Novel Derivatives of Isoxazolo[4,5e][1,2,4]triazepine Derivatives and Potential Inhibitors of Protein Kinase C. ACS Omega 2020, 6, 119-134. [CrossRef] 